TARÓDY, Dávid

\title{
ORGANIZATIONAL AMBIDEXTERITY AS A NEW RESEARCH PARADIGM IN STRATEGIC MANAGEMENT
}

Long-term survival and growth depends on the firm's ability to exploit its current competencies while exploring fundamentally new ones. Finding the balance between exploration and exploitation is called ambidexterity in the literature. This paper is a comprehensive review of organizational ambidexterity theory. Creating and maintaining the capacity to simultaneously pursue these contradictory activities is an extremely difficult managerial challenge. Although, several aspects are well-researched, especially structural and leadership solutions in large, multinational enterprises, but little is known about: (1) how ambidexterity forms in earlier growth stages? (2) What are the key drivers and elements of organizational context that makes organizations able to become ambidextrous? (3) What is the role of different managerial levels in this formation process? Reviewing the literature, in this article the author would like to introduce the paradox of exploration and exploitation, the tensions and different aspects of ambidexterity, the fields current stage and some important research gaps.

Keywords: organizational ambidexterity, structural ambidexterity, contextual ambidexterity, exploration, exploitation

Organizations face continuously accelerating macro-, industrial- and micro-level environmental changes that challenge them to become dynamic and adapt properly to the turbulent and heterogeneous context (Balaton et al., 2014; Balaton - Tari, 2014; D’Aveni, 1994; Mészáros, 2010; Szabó, 2008). A central concern of corporate strategy is the constraint of making definite choices about how much to invest in different types of activities. To achieve long-term prosperity, it is essential to continuously adapt to external threats and opportunities and respond with innovations and structural alignments. In stable environments, this requires "mechanistic management systems", and under turbulent circumstances, organic systems are necessary (Burns - Stalker, 1961; Schumpeter, 1934; Tushman - O'Reilly, 2002). But there aren't any markets that are stable forever - change is inevitable. There is an interdependence between the key activities. Without exploiting existing business models, organizations cannot afford to invest in the future and sustain stability and steady performance. Burgelman (1991) in his adaptation paradox stated that concentrating on the present reduces the ability to prepare for challenges in the future.

A recurring theme in organizational literature is that successful organizations in a dynamic environment are ambidextrous: they are aligned and efficient in the pres- ent, but able to adapt to future changes (Birkinshaw - Gibson, 2004; Duncan, 1976; Tushman - O'Reilly, 1996). Long-term success depends on the organization's ability to exploit its current capabilities while simultaneously exploring fundamentally new competencies, products, technologies and markets (Levinthal - March 1993, March 1991). An appropriate balance between exploration and exploitation is necessary for a firm to be both competitive in mature markets and innovative in emerging ones (Tushman - O'Reilly, 1996). The capacity to pursue these two contradictory objectives simultaneously, namely being both cost-effective and productive, explorative and flexible at the same time, is called ambidexterity (Smith - Tushman, 2005).

March's (1991) argument in his seminal work was that successful organizations are ambidextrous. This contributed to a general shift in organizational research to understand and perceive this issue as a paradox (Eisenhardt, 2000; Gavetti - Levinthal, 2000; Lewis, 2000), and not a trade-off that is impossible to resolve (Hannan - Freeman, 1977; McGill - Slocum - Lei, 1992).

In this article, I would like to introduce the fundamental elements and different subfields of organizational ambidexterity, because it is one of the most active 
fields in strategic management literature nowadays. Little, however, is known about its evolution, therefore I would like to introduce important research gaps based on the most comprehensive typologies in the field (Lavie - Stettner - Tushman, 2010; O'Reilly - Tushman, 2013; Raisch - Birkinshaw, 2008; Simsek et al., 2009).

\section{Literature review}

Markets allocate resources efficiently to their short-term best use, whereas firms should have the capacity and managerial competence to transform them into outputs that have the potential to create new value in the long term (Birkinshaw - Gupta, 2013). Birkinshaw and Gupta (2013) therefore suggested that firms have to seek to achieve some form of ambidexterity to manage the tensions and contradictions between the two different learning activities: exploration and exploitation. March (1991) described these competing activities as self-reinforcing patterns of learning and stated that while not impossible, it is extremely difficult to overcome these path dependencies and find balance between them. Exploration requires search, discovery, experimentation, risk-taking and innovation, while exploitation consists of behavioral patterns characterized by refinement, implementation, efficiency, production and selection (Cheng - Van de Ven, 1996; March 1991). The key issue in ambidexterity is the quality of management and not its existence per se, because top managers are the only decision-makers able to make trade-offs among these competing objectives and reduce the organization's tendency to follow the easiest route (Birkinshaw - Gupta, 2013).

Ambidexterity is hard to achieve, because managers should make thoughtful trade-offs shaped by self-reinforcing routines, short-term interests and unseen factors to decide whether present benefits should be sacrificed for future success (Ghoshal - Bartlett, 1994; Crozier, 1964; March, 1991; Prahalad - Bettis, 1984; Smith Lewis, 2011). This trade-off is the central premise of March's (1991) framework, which sets out that managers' decision-making is distracted by self-reinforcing routines, temporal contradictions and limited resources. Although both activities are critical for long-term survival and growth, they are fundamentally different logics that compete for the same scarce resources. This limited resource availability constrains firms to favor one type of activity over the other, which results in the firm becoming trapped (March 1991; Levinthal - March 1993).

\section{Long-term effects of focus: the traps of excessive exploration or exploitation}

Theoretically, organizations should trade off short-term efficiency and profit for long-term innovation to create prospective opportunities, instead of investing only in short-term productivity (March, 1991). The returns from exploration are, however, less certain, more variable and more remote. The probability that they will occur, and the direct effect of current actions on future opportunities are less tangible and perceptible (March, 1991). The returns associated with exploitation are more certain, tangible and immediate. Without investing in exploration of new knowledge and market opportunities, however, organizations cannot ensure their future prosperity. Allocating excessive amounts of resources to the incremental development of existing technologies and processes leads to immediate reliability, effectiveness and productivity, but increases the risk of becoming obsolete in the future (Chesbrough - Rosenbloom, 2002; Holmqvist, 2004; Leonard-Barton, 1992).

A focus on stability creates structural inertia, making it difficult for the organization to adapt to environmental threats and new opportunities. Too much experimenting, however, reduces the speed at which existing competencies are refined (Hannan - Freeman, 1977, 1984; Lewin - Long - Carroll, 1999; March, 1991). Exploitation-oriented organizations face serious challenges when they are forced to change strategy and focus, because they have traded flexibility for stability in the past (Hannan - Freeman, 1977, 1984): "an organization that engages exclusively in exploitation will suffer from obsolescence" (Levinthal - March, 1993, p. 105.). The self-reinforcing nature of organizational learning makes it attractive for a firm to focus on the present and under-estimate the threats of environmental changes against the costs of changing current capabilities. This can cause core capabilities to be turned into core rigidities (Leonard-Barton, 1992, 1995), creating competency and exploitation traps (Ahuja - Lampert, 2001; Fauchart - Keilbach, 2009; Herriott - Levinthal - March, 1985; Levitt - March, 1988). The excessive focus on exploitation results in organizational myopia and competency traps (Levitt - March 1988). According to D'Aveni (1994), this is a very dangerous position because under hyper-competitive circumstances, no firm can build a sustainable competitive advantage, because today's strength quickly becomes tomorrow's weakness.

Instead of trying to find stability, firms must interpret their core competencies as temporary advantages and therefore actively create a series of new ones (D'Aveni, 1994), but being too explorative could be also dangerous. A failed explorative effort may disrupt successful routines and the full utilization of existing competencies without any significant financial compensation for the future loss of existing business (Mitchell - Singh, 1993; Volberda, 1996; Volberda - Lewin, 2003). In other words, explorative firms generate larger performance 
variation by experiencing substantial success as well as failure, while exploitative firms are likely to generate more stable performance. Both strategies, however, are unsustainable in the long term ( $\mathrm{He}$ - Wong, 2004).

Excessive exploration is equally destructive and can cause a self-reinforcing exploration trap. Market failure ideally leads to search and change, but new failures in this process can lead to even more change, and this focus may harm present profitability and make future operation impossible (Levinthal - March, 1993). According to He and Wong (2004), the inability of many innovative firms to achieve market success can be traced partly to their tendency to explore new products and unfamiliar markets constantly without allocating enough resources to exploit them.

Long-term success is only sustainable by balancing exploration and exploitation. Managing these contradictory activities within one organization is extremely challenging, because temporal and perceptual discrepancies in the trade-off between exploration and exploitation create path dependencies, which can distract managers' decision-making and lead to inappropriate adaptations by favoring one activity or the other (Benner - Tushman, 2002; Levinthal - March, 1993).

\section{Historical approach of the literature's development}

Organizational ambidexterity's fundamental premise is that strategic decisions are to some degree always in conflict, and managers are therefore forced to handle trade-offs. These paradoxical decisions are extremely difficult to make. Previous scholars found it hard to conceptualize how an organization could combine short-term efficiency and long-term efficacy, because these two domains were based on different competences (Christensen - Overdorf, 2000; Benner - Tushman, 2003). Earlier studies often described the trade-offs between these two activities as insurmountable (Hannan - Freeman, 1977; McGill - Slocum - Lei, 1992). Porter (1996), for instance, argued that low-cost-production and product differentiation were not compatible and combinable strategies, and suggested that organizations had to make explicit choices.

By contrast, the literature on organizational ambidexterity argues that trade-offs can never entirely be eliminated, but that to enhance long-term competitiveness and growth, organizations should reconcile them as far as possible, instead of focusing on one or the other (Gibson - Birkinshaw, 2004; March, 1991). Duncan (1976) was the first, who applied the term organizational ambidexterity, but March's (1991) seminal work was the first catalyst of the field. March interpreted exploitation and exploration as two basically different learning activities between which organizations should divide their attention. In his definition, exploitation refers to "refinement, efficiency, selection, and implementation," whereas exploration is interpreted as "search, variation, experimentation, and discovery" (March, 1991, p. 102.).

The first and still the most popular and well-researched field of organizational ambidexterity became the structural aspect. This concept is based on the organizational design literature (i.e. Burns - Stalker, 1961; Duncan, 1976; Lawrence - Lorsch, 1967), which solves the paradox of concurring activities with structural separation of exploration and exploitation into independent units but with a leadership-integration and coordination at the top of the organization (Drucker, 1985; Galbraith, 2002). Tushman and O'Reilly's (1996) important article catalyzed the interest in the structural and leadership-based ambidexterity.

The second important and influential concept of organizational ambidexterity is the contextual aspect. Gibson and Birkinshaw (2004) in their field-changing work suggest that ambidexterity can be best achieved by building business unit context to encourage individuals to participate in both exploration and exploitation, rather than by structural separation. This model eliminates the coordination costs and facilitates whole-organization adaptation, but generates new management issues.

To conclude, ambidextrous organization achieves balance between alignment and adaptation by developing (1) dual structures (Duncan, 1976; Tushman - O’Reilly, 1996) or (2) ambidextrous organizational context (Gibson - Birkinshaw, 2004), to reconcile the conflicting demands for exploration and exploitation. Although there are differences between the subfields of ambidexterity literature, they agree that ambidextrous organizations are likely to have superior performance. Large-scale empirical studies provided evidence of the generally positive association between organizational ambidexterity and firm performance (e.g. Gibson - Birkinshaw, 2004; He - Wong, 2004; Kouropalatis - Hughes - Morgan, 2012; Lubatkin et al., 2006). In this chapter, I would like to introduce ambidexterity's fundamental premises and the two most important subfields, the structural aspect and contextual ambidexterity.

\section{Paradoxes in the existing literature - different interpretation of the exploration-exploitation contradiction in organizational theories}

Organizations are attempting to address many types of contradictions, such as exploration and exploitation, efficiency and flexibility, adaptability and alignment, and integration and responsiveness (Gulati - Puranam, 2009). Since March's seminal work (1991), the 
Table 1

Paradoxes in management theories (Source own work based on Raisch _ Birkinshaw, 2008), source: own work based on Raisch - Birkinshaw (2008)

\begin{tabular}{|c|c|c|c|c|c|}
\hline Discipline & Paradox & Definition & Selected authors & Exploitation & Exploration \\
\hline \multirow{3}{*}{$\begin{array}{l}\text { Organizational } \\
\text { learning }\end{array}$} & \multirow{3}{*}{$\begin{array}{l}\text { The well-balanced combination of two } \\
\text { fundamentally different, and basically } \\
\text { incompatible learning types (explo- } \\
\text { ration vs. exploitation (March, 1991), } \\
\text { single-loop vs. double-loop learning } \\
\text { (Argyris - Schön, 1978), generative vs. } \\
\text { adaptive learning (Senge, 1990) and } \\
\text { local search vs. long jump (Levinthal, } \\
\text { 1997)) is essential for long-term success } \\
\text { (Gupta et al., 2006; Levinthal - March, } \\
\text { 1993; March, 1991). }\end{array}$} & \multirow{3}{*}{$\begin{array}{l}\text { "Exploitation refers to learning } \\
\text { gained via local search, experien- } \\
\text { tial refinement, and selection and } \\
\text { reuse of existing routines. Explo- } \\
\text { ration refers to learning gained } \\
\text { through processes of concerted } \\
\text { variation, planned experimenta- } \\
\text { tion, and play" (Baum - Li - Ush- } \\
\text { er, 2000, p.768.). }\end{array}$} & \multirow{3}{*}{$\begin{array}{l}\text { Argyris - Schön (1978); } \\
\text { Gupta et al. (2006); Levinthal } \\
\text { (1997); Levinthal - March } \\
\text { (1993); March (1991); Senge } \\
\text { (1990) }\end{array}$} & $\begin{array}{l}\text { Single-loop learn- } \\
\text { ing }\end{array}$ & $\begin{array}{l}\text { Double-loop } \\
\text { learning }\end{array}$ \\
\hline & & & & $\begin{array}{l}\text { Generative learn- } \\
\text { ing }\end{array}$ & $\begin{array}{l}\text { Adaptive learn- } \\
\text { ing }\end{array}$ \\
\hline & & & & Local search & Long jump \\
\hline $\begin{array}{l}\text { Organizational } \\
\text { design }\end{array}$ & $\begin{array}{l}\text { Organizations require mechanistic } \\
\text { and organic structures to innovate and } \\
\text { implement (Burns - Stalker, 1961; } \\
\text { Duncan, 1976; Lawrence - Lorsch, } \\
\text { 1967). Firms combine mechanistic and } \\
\text { organic features within one organiza- } \\
\text { tional context (Gibson - Birkinshaw) } \\
\text { or separate them structurally (Tushman } \\
\text { - O'Reilly). }\end{array}$ & $\begin{array}{l}\text { A firm's ability to operate com- } \\
\text { plex organizational designs that } \\
\text { provide for short-term efficiency } \\
\text { and long-term innovation (Raisch } \\
\text { - Birkinshaw, 2008). }\end{array}$ & $\begin{array}{l}\text { Burns - Stalker (1961); } \\
\text { Duncan (1976); Ford - Ford } \\
\text { (1994); Gibson - Birkinshaw } \\
\text { (2004); Lawrence - Lorsch } \\
\text { (1967); Lewis (2000); } \\
\text { Thompson (1967); Thusman - } \\
\text { O'Reilly (1996) }\end{array}$ & $\begin{array}{l}\text { Mechanistic struc- } \\
\text { tures }\end{array}$ & $\begin{array}{l}\text { Organic struc- } \\
\text { tures }\end{array}$ \\
\hline $\begin{array}{l}\text { Organizational } \\
\text { adaptation }\end{array}$ & $\begin{array}{l}\text { Organizations need to balance continu- } \\
\text { ity and change for long-term success. } \\
\text { Long periods of continuity in organ- } \\
\text { izational evolution are punctuated by } \\
\text { short, radical transformations (Tush- } \\
\text { man - Romanelli, 1985). }\end{array}$ & $\begin{array}{l}\text { An organization's capacity for } \\
\text { change depends on its ability to } \\
\text { balance the need to implement } \\
\text { radical changes and to maintain } \\
\text { daily operations (Meyes - Sten- } \\
\text { saker, 2006). }\end{array}$ & $\begin{array}{l}\text { Brown - Eisenhardt (1997); } \\
\text { Leana - Barry (2000); Huy } \\
\text { (2002); Meyer and Stensaker } \\
\text { (2006); Miller - Friesen } \\
\text { (1984); Probst - Raisch (2005); } \\
\text { Tushman - Romanelli (1985) }\end{array}$ & Continuity & Change \\
\hline $\begin{array}{l}\text { Strategic man- } \\
\text { agement }\end{array}$ & $\begin{array}{l}\text { Both variation-reducing, induced } \\
\text { strategic processes that are within the } \\
\text { scope of current corporate strategy, } \\
\text { and variation-increasing, autonomous } \\
\text { strategic processes, outside current } \\
\text { strategic scope, compete for the same } \\
\text { scarce resources. Managers therefore } \\
\text { need to make trade-offs between them } \\
\text { (Burgelman, 1991, 2002). }\end{array}$ & $\begin{array}{l}\text { "Combination of the two strategic } \\
\text { processes may be the most bene- } \\
\text { ficial, because organizations may } \\
\text { have to keep both processes in } \\
\text { play at all times, even though this } \\
\text { means that the organization never } \\
\text { completely maximizes its efforts in } \\
\text { the current domain" (Burgelman, } \\
\text { 1991, p. 256.). }\end{array}$ & $\begin{array}{l}\text { Burgelman (1991, 2002); Ghe- } \\
\text { mawat - Ricart i Costa (1993); } \\
\text { Hamel - Prahalad (1993); }\end{array}$ & $\begin{array}{l}\text { Induced strategic } \\
\text { process }\end{array}$ & $\begin{array}{l}\text { Autonomous } \\
\text { strategic process }\end{array}$ \\
\hline $\begin{array}{l}\text { Innovation } \\
\text { management }\end{array}$ & $\begin{array}{l}\text { The capability-rigidity paradox de- } \\
\text { scribes the tensions that emerge when } \\
\text { organizations handle both radical and } \\
\text { incremental innovations simultaneous- } \\
\text { ly, because exploiting existing product } \\
\text { innovation capabilities may have dys- } \\
\text { functional rigidity effects that could } \\
\text { prevent the development of new capa- } \\
\text { bilities (Leonard-Barton, 1992). }\end{array}$ & $\begin{array}{l}\text { "Ambidexterity is a firm's ability } \\
\text { to simultaneously pursue both } \\
\text { incremental and discontinuous } \\
\text { innovation" (Tushman - O>Reilly, } \\
\text { 1996, p. 24.). }\end{array}$ & $\begin{array}{l}\text { Abernathy - Clark (1985); } \\
\text { Dougherty (1992); Dewar - } \\
\text { Dutton (1986); Leonard-Bar- } \\
\text { ton (1992); Tushman - Ander- } \\
\text { son (1986); Sheremata (2000) }\end{array}$ & $\begin{array}{l}\text { Incremental inno- } \\
\text { vation }\end{array}$ & $\begin{array}{l}\text { Radical inno- } \\
\text { vation }\end{array}$ \\
\hline $\begin{array}{l}\text { Entrepreneur- } \\
\text { ship }\end{array}$ & $\begin{array}{l}\text { Entrepreneurship is the creative dis- } \\
\text { ruption of market equilibrium by new } \\
\text { products and business models (Schum- } \\
\text { peter, 1934). The continuous pursuit } \\
\text { of innovation is an essential part of } \\
\text { entrepreneurial behavior (Drucker, } \\
\text { 1998), but an entrepreneur also has to } \\
\text { pay attention to developing structures } \\
\text { and systems to exploit opportunities } \\
\text { (Stevenson - Gumpert, 1985). }\end{array}$ & $\begin{array}{l}\text { The entrepreneur should be aware } \\
\text { of market opportunities and able } \\
\text { to exploit them by managing } \\
\text { resource allocation, control and } \\
\text { structures (Stevenson - Gumpert, } \\
\text { 1985). }\end{array}$ & $\begin{array}{l}\text { Carland et al. (1984); Cole } \\
\text { (1968); Drucker (1969, 1998); } \\
\text { Schumpeter (1934); Stevenson } \\
\text { - Gumpert (1985) }\end{array}$ & $\begin{array}{l}\text { Administrative } \\
\text { management }\end{array}$ & $\begin{array}{l}\text { Disruptive } \\
\text { innovation }\end{array}$ \\
\hline \multirow{2}{*}{ Growth theory } & \multirow{2}{*}{$\begin{array}{l}\text { Organizations inevitably meet spe- } \\
\text { cific growth crises during their life } \\
\text { cycle. These crises emerge from the } \\
\text { imbalance between exploration and } \\
\text { exploitation, because the previously } \\
\text { appropriate organizational context can } \\
\text { no longer handle increased market size, } \\
\text { employees, processes, structures and } \\
\text { complexity (Greiner, 1972). }\end{array}$} & \multirow{2}{*}{$\begin{array}{l}\text { A company cannot grow efficient- } \\
\text { ly if growth rate is faster than the } \\
\text { development of managerial knowl- } \\
\text { edge and skills (Penrose, 1959). }\end{array}$} & \multirow{2}{*}{$\begin{array}{l}\text { Greiner (1972); Penrose } \\
(1959)\end{array}$} & Change in quantity & $\begin{array}{l}\text { Change in } \\
\text { quality }\end{array}$ \\
\hline & & & & Growth period & Growth crisis \\
\hline
\end{tabular}


distinction between exploration and exploitation has been widely used in various fields outside organizational learning, including innovation management (Birkinshaw et al., 2008; Cheng - Van de Ven, 1996; He - Wong, 2004; Jansen et al., 2006; O'Reilly - Tushman, 2004; Smith - Tushman, 2005), strategic management (e.g. Winter - Szulanski, 2001), organization theory (e.g. Holmqvist, 2004; Van den Bosch et al., 1999), and managerial economics (e.g., Ghemawat - Ricart i Costa, 1993). These studies have examined in depth the organizational requirements and effects on firm performance of exploration and exploitation. They showed that exploration is associated with organic structures, loosely coupled systems, path-breaking, improvisation, autonomy and chaos, and emerging markets and technologies (He - Wong, 2004). Exploitation is associated with rigid structures, tightly coordinated systems, path dependency, processes, control and bureaucracy, and stable markets and technologies (Ancona et al. 2001, Brown - Eisenhardt 1998, Lewin et al. 1999). Birkinshaw and Gupta (2013) suggested using ambidexterity as a conceptual framework in all fields of management literature to frame research questions. Table 1 . sets this out in full.

Consequently, organizational ambidexterity can be defined in multiple ways in various fields of organizational theory, for example, as firms' ability to simultaneously manage double-loop and single-loop learning (Argyris - Schön, 1978) or local search and long jump (Levinthal, 1997), incremental and radical innovation (e.g. Abernathy - Clark, 1985; Dewar - Dutton, 1986; Tushman - Anderson, 1986), and stability and transformation in organizational adaptation (Romanelli - Tushman, 1985).

The question emerges, then does ambidexterity really exist, or is it just a reinterpretation of previous findings (Birkinshaw - Gupta, 2013)? The answer is, that there is nothing new in the basic problem, but the approach. Other fields usually define exploration and exploitation of a continuum's two ends, where these activities are in insurmountable contradiction. Ambidexterity suggests, that trade-offs, however, can never be perfectly eliminated, but managers have different structural, contextual and leadership-solutions to reconcile this conflict as deep as possible. Therefore, Birkinshaw and Gupta (2013) interpreted ambidexterity as a universal conceptual framework to frame research questions addressing the exploration-exploitation paradox.

\section{Different constructs of ambidexterity}

According to Raisch and Birkinshaw (2008), organizational ambidexterity is becoming a research paradigm in organizational theory. There are currently several

different trends in the field but these approaches have started to merge in recent studies (e.g. Birkinshaw Gibson, 2004; Chen - Katila, 2008; Kauppila, 2010; O’Reilly - Tushman, 2013).

\section{Tensions in the organizational ambidexterity literature}

Figure 1

\section{Tensions in organizational ambidexterity}

Differentiation
Individual
Static
Internal

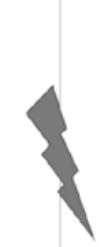

\author{
Integration
}

Organization

Dynamic

External

Raisch et al. (2009) defined four tensions in the field of organizational ambidexterity: differentiation vs. integration, individual vs. organization, static vs. dynamic and internal vs. external (see Figure 1). The tension of differentiation and integration separates researches in two groups. Researches articulating the importance of differentiation emphasize that ambidexterity can only be achieved by separation of exploitative and explorative activities into distinct structural units (Benner Tushman 2003; Christensen 1998; Tushman - O'Reilly, 1996). According to the other group of authors, integration refers to the contextual approach that focuses on the creation of an organizational context to enable employees to pursue both types of activities within one business unit (Gibson - Birkinshaw, 2004). This distinction separates the two most important aspect, the structural and contextual ambidexterity that I will introduce in the following chapter.

Besides the differentiation-integration tension, there are other focal differences in the literature. The individual vs. organization tension focuses on the differences between individual or organizational level manifestation of ambidexterity. The third tension is between static and dynamic perspectives (Raisch et al., 2009). In the dynamic aspect, the majority of organizational ambidexterity research focuses on the issues, contradictions and organizational or leadership solutions required to become simultaneously ambidextrous (e.g., Gibson - Birkinshaw, 2004; Gupta et al., 2006; Raisch - Birkinshaw, 2008; Tushman - O'Reilly, 1996).

Researchers of the static view suggests that firms may temporarily oscillate between periods of explo- 
ration and exploitation, and that sequential attention should be paid to the two (e.g., Brown - Eisenhardt, 1997, 1998; Burgelman, 2002; Gupta et al., 1996; Laplume - Dass, 2012; Rothaermel - Deeds, 2004; Siggelkow - Levinthal 2003).

Finally, the fourth tension in the field relates to internal versus external perspectives. According to Raisch et al. (2009), research has generally focused on how organizations address exploitation and exploration internally (e.g. Benner - Tushman, 2003; Gibson - Birkinshaw, 2004). The typical level of analysis was organization, business unit and individual.

But there are other suggestions in the literature to structurally separate exploitation and exploration via the externalization one or the other, by outsourcing or establishing alliances (Baden-Fuller - Volberda, 1997; Holmqvist, 2004; Kauppila, 2010; Lavie - Rosenkopf, 2006; Rothaermel - Deeds, 2004; Russo - Vurro, 2010).

Table 2

\section{Classification of ambidexterity research}

\section{(O'Reilly - Tushman, 2013; Raisch - Birkinshaw, 2008; Simsek et al., 2009)}

\begin{tabular}{|c|c|c|}
\hline Raisch - Birkinshaw (2008) & Simsek et al. (2009) & O'Reilly - Tushman (2013) \\
\hline Contextual ambidexterity & Harmonic ambidexterity & Contextual ambidexterity \\
\hline $\begin{array}{l}\text { Rather than creating dual structural arran- } \\
\text { gements, leaders are expected to create a } \\
\text { supportive business-unit context. Context } \\
\text { refers to the systems, processes and beliefs } \\
\text { that shape individual-level behaviors in an } \\
\text { organization. Successful organizations are } \\
\text { expected to balance the hard (discipline } \\
\text { and stretch) and soft (support and trust) } \\
\text { elements in their organizational contexts } \\
\text { (Bartlett - Ghoshal, 1989; Ghoshal - Bart- } \\
\text { lett, 1994). }\end{array}$ & $\begin{array}{l}\text { Concurrently pursuing exploitation and } \\
\text { exploration harmoniously within a single } \\
\text { organizational unit is inherently challen- } \\
\text { ging, because each competes for scarce } \\
\text { resources, leading to conflicts, contradicti- } \\
\text { ons, and inconsistencies. In the absence of } \\
\text { partitioning, this pursuit becomes intertwi- } \\
\text { ned in the ongoing operating and strategic } \\
\text { activities of the unit in its culture, structure, } \\
\text { and systems, placing a premium on its } \\
\text { members' integrative abilities. }\end{array}$ & $\begin{array}{l}\text { Contextual ambidexterity is the behavioral } \\
\text { capacity to simultaneously demonstrate } \\
\text { alignment and adaptability across an entire } \\
\text { business unit. The ability that makes the } \\
\text { unit/organization able to balance between } \\
\text { exploration and exploitation is the organi- } \\
\text { zational context characterized by an in- } \\
\text { teraction of stretch, discipline, and trust. }\end{array}$ \\
\hline Structural ambidexterity & Partitional ambidexterity & Simultaneous / Structural ambidexterity \\
\hline $\begin{array}{l}\text { Ambidexterity in organizational structu- } \\
\text { res is achieved by developing structural } \\
\text { mechanisms to cope with the competing } \\
\text { demands faced by the organization for } \\
\text { alignment and adaptability (Gibson - Bir- } \\
\text { kinshaw, 2004, p. 211.). }\end{array}$ & \multirow{3}{*}{$\begin{array}{l}\text { Pursuing ambidexterity requires the estab- } \\
\text { lishment of structurally independent units } \\
\text { each having its own strategies, structures, } \\
\text { cultures, and incentive systems. From a } \\
\text { managerial perspective, several characte- } \\
\text { ristics of senior management teams serve } \\
\text { as important antecedents to this form of } \\
\text { ambidexterity. }\end{array}$} & \multirow{3}{*}{$\begin{array}{l}\text { Simultaneous or structural ambidexterity is } \\
\text { a way of balancing the exploration/exploi- } \\
\text { tation trade-off by using organizationally } \\
\text { separate but strategically integrated subu- } \\
\text { nits with different competencies, systems, } \\
\text { incentives, processes, and cultures, each } \\
\text { internally aligned (O'Reilly et al., 2009; } \\
\text { O'Reilly - Tushman, 2004). This is a le- } \\
\text { adership issue more than a structural one } \\
\text { (O'Reilly - Tushman, 2011; Smith- Binns - } \\
\text { Tushman, 2010; Smith - Tushman, 2005). }\end{array}$} \\
\hline Leadership-based ambidexterity & & \\
\hline \multirow{5}{*}{$\begin{array}{l}\text { Ambidexterity is facilitated by the top ma- } \\
\text { nagement team's internal processes (Tus- } \\
\text { hman - O'Reilly, 1997). Senior executives } \\
\text { are important "in making an organization } \\
\text { context effective and developing ambidext- } \\
\text { erity" (Gibson - Birkinshaw, 2004, p. 223; } \\
\text { Smith - Tushman, 2005). }\end{array}$} & & \\
\hline & Cyclical ambidexterity & Sequential ambidexterity \\
\hline & $\begin{array}{l}\text { Cyclical ambidexterity, in which organi- } \\
\text { zations engage in long periods of exploi- } \\
\text { tation (or relative stability), interspersed } \\
\text { with sporadic episodes of exploration (or } \\
\text { change), is attained not by structural par- } \\
\text { titioning, but by sequentially allocating } \\
\text { resources and attention to exploitation and } \\
\text { exploration. This type of ambidexterity } \\
\text { involves a system of temporal cycling in } \\
\text { which organizations alternate between long } \\
\text { periods of exploitation and short bursts of } \\
\text { exploration. }\end{array}$ & $\begin{array}{l}\text { Firms evolve through punctuated chan- } \\
\text { ges in which they adapt sequentially to } \\
\text { environmental shifts by realigning their } \\
\text { structures and processes. }\end{array}$ \\
\hline & Reciprocal ambidexterity & \\
\hline & $\begin{array}{l}\text { Reciprocal ambidexterity is best portrayed } \\
\text { as being a synergistic fusion of comple- } \\
\text { mentary streams of exploitation and explo- } \\
\text { ration that occur across time and units. }\end{array}$ & \\
\hline
\end{tabular}


Drawing on these tensions, Raisch and Birkinshaw (2008), Simsek and colleagues (2009) and O'Reilly and Tushman (2013) provided deep and detailed categorization and conceptualization for the field. Raisch and Birkinshaw (2008) identified three distinct but broad subcategories within the ambidexterity literature: structural and contextual (which differ most importantly in structural integration and differentiation), and leadership-based, which focus on the responsibility of management teams in handling the contradictory forces and tensions. Simsek et al. (2009) identified two distinct dimensions of ambidexterity. The first is temporal, capturing the distinction between the simultaneous and sequential aspects. Like Raisch and Birkinshaw's (2008), their second dimension focuses on the differences between integrated and separated organizational solutions. Simsek et al. (2009) created a two-by-two typology that differentiates four types of ambidexterity: harmonic, cyclical, partitional and reciprocal. O'Reilly and Tushman (2013) reviewed the evidence and results of sequential, simultaneous, structural and contextual ambidexterity. Comparing the classifications, I suggest two important consequences. First, the integration vs. differentiation (separation) tension is the most significant in the literature, and I will discuss these aspects in more detail. Second, Simsek at al. (2009) and O'Reilly and Tushman do not differentiate between structural- and leadership-based solutions to ambidexterity. They interpret these results as complementary solutions. Table 2 sets out the classifications and definitions of the subcategories.

\section{Structural and contextual ambidexterity, the field's two most important aspects}

The structural antecedents of ambidexterity have long been a focus of research interest, other aspects of it, such as its contextual antecedents, are under-researched. A wide range of research has focused on mature, multinational corporations that have successfully applied ambidextrous structures. As Birkinshaw and colleagues (2014) argued, however, little is known about how ambidexterity, this complex and nested construct, forms and develops. Researchers need to understand how firms or business units develop organizational contexts that separate explorative and exploitative tasks at the personal level. In Table 3, I introduce and highlight the differencies of structural and contextual ambidexterity, then in the following subchapters I explain these aspects in detail.

\section{Introduction of contextual ambidexterity}

Gibson and Birkinshaw (2004:209) defined contextual ambidexterity as the behavioral capacity to simultaneously achieve alignment and adaptability at business unit level, where alignment is coherence among all the patterns of activities in the business unit (exploitation), and adaptability is the capacity to quickly reconfigure activities in the business unit to meet changing demands in the task environment (exploration).

In Gibson and Birkinshaw's (2004, p. 210.) interpretation, contextual ambidexterity differs significantly from the construct of structural ambidexterity emerging from the work of Duncan (1976) and Tush-

\section{Comparison of structural and contextual ambidexterity}

Table 3

\begin{tabular}{|c|c|c|}
\hline & Structural ambidexterity & Contextual ambidexterity \\
\hline How is ambidexterity achieved? & $\begin{array}{l}\text { Alignment- and adaptability-fo- } \\
\text { cused activities are carried out in } \\
\text { separate units or teams }\end{array}$ & $\begin{array}{l}\text { Individual employees divide their } \\
\text { time between alignment- and adap- } \\
\text { tability-focused activities }\end{array}$ \\
\hline $\begin{array}{l}\text { Where are decisions made about } \\
\text { the split between alignment and } \\
\text { adaptability? }\end{array}$ & At the top of organization & $\begin{array}{l}\text { On the frontline, by salespeople, } \\
\text { plant supervisors, and office workers }\end{array}$ \\
\hline Role of top management & $\begin{array}{l}\text { To define the structure, and make } \\
\text { trade-offs between alignment and } \\
\text { adaptability }\end{array}$ & $\begin{array}{l}\text { To develop the organizational cont- } \\
\text { ext }\end{array}$ \\
\hline Nature of roles & Relatively clearly defined & Relatively flexible \\
\hline Skills of employees & More specialists & More generalists \\
\hline
\end{tabular}


man - O'Reilly (1996), because "ambidexterity is best achieved not through the creation of dual structures, but by building a set of processes or systems that enable and encourage individuals to make their own judgments about how to divide their time between conflicting demands for alignment and adaptability."

The construct of context is based on Ghoshal and Bartlett (1994), who identified discipline, stretch, trust and support as key factors of the context. Discipline consists of clear standards and expectations of performance and behavior, a system of open and fast-cycle feedback, and a consistent system of sanctions. Stretch covers the management responsibilities for establishing shared ambition, creating collective organizational identity and giving personal meaning to the individual contribution to firm-level performance. Trust was interpreted as a higher level of perceived fairness in the decision-making processes, broader involvement in core activities and an increase in overall level of personal competence. Finally, support is identified as an organizational element giving greater availability of resources, greater autonomy and more support for initiatives.

Gibson and Birkinshaw (2004) noted that structural and contextual approaches cannot be concurrent, but suggest that ambidexterity is best achieved by building business unit context to encourage individuals to participate in both types of activities, rather than by task or structural separation. In their view, this is a more sustainable model because it eliminates the coordination costs of separate business units and facilitates whole-organization adaptation. Although contextual ambidexterity's basis is the unit's systems and processes, it manifests in the actions of individuals: "when contextual ambidexterity has been achieved, every individual in a unit can deliver value to existing customers in his or her own functional area, but at the same time every individual is on the lookout for changes in the task environment, and acts accordingly (p. 211.)."

As a consequence, Gibson and Birkinshaw's (2004) results are widely interpreted as an individual approach to ambidexterity, but they clearly declared in their original article that this is a multi-level construct, where the context is the reason and behavior is the effect. They (Birkinshaw - Gibson, 2004, p. 50.) defined the construct as "the individual's ability to exhibit ambidexterity is facilitated (or constrained) by the organizational context in which he or she operates, so contextual ambidexterity can also be diagnosed and understood as a higher-order organizational capability. At the organizational level, contextual ambidexterity can be defined as the collective orientation of the employees toward the simultaneous pursuit of alignment and adaptability."

Brion, Mothe and Sabatier (2010) also provided evidence of the strong impact of organizational context on ambidexterity, and their findings emphasized the key role of managers, supporting the earlier work of Mom and colleagues (2007) and O'Reilly and Tushman (2008). They suggested that organizations should motivate managers to create an appropriate context, because developing supportive short- and long-term organizational focus increases ambidexterity. Performance management and reward systems should focus on developing both sets of competences, because the incentives given to employees through the systems of organizational context should be in line with strategic goals and activities of the top management. This alignment could lead to contextual ambidexterity at the organizational level.

\section{Introduction of structural ambidexterity}

The research on structural ambidexterity is the broadest and deepest field in the domain. Duncan (1976) argued that firms need to support constantly innovative operations with a dual structure, both to find new opportunities and to deliver results. The concept of structural partitioning/differentiation traces its roots back to the literature of organizational design, which emphasizes the importance of maintaining congruence between organizational structure and the demands of the task environment (Burns - Stalker, 1961; Duncan, 1976; Lawrence - Lorsch, 1967). The best way to create and maintain this consistency is to separate business development activities into independent units, although this creates coordination costs at the corporate level (Drucker, 1985; Galbraith, 2002; Tushman - O'Reilly, 1996). This structural differentiation can help ambidextrous organizations to maintain different competencies. It can therefore lead to superior short and long-term performance in companies facing multiple strategic challenges, for example, in an international context (Gilbert, 2005; Han 2007; Han - Celly 2008).

Scholars agree that structural ambidexterity is not just a simple organizational design solution of the exploration-exploitation trade-off, because different management teams, competencies, systems, incentives, processes and cultures need to be established, maintained and, most importantly, held together and internally aligned by a common strategic intent (O'Reilly - Tushman, 2004; O'Reilly - Tushman, 2008; O'Reilly et al., 2009; Mahmoud-Jouini - Charue-Duboc - Fourcade, 2007).

To conclude ambidexterity is more than the presence of exploration and exploitation, and this difference is articulated at the structural level. Although each unit is independent, they operate interdependently, and creating the required coordination mechanism is an issue of leadership rather than structure (O'Reilly - Tushman, 2008, 2011; Smith - Binns - Tushman, 2010; Smith Tushman, 2005). Typical mechanisms are shared vision, 
senior management team coordination, and knowledge integration systems (Jansen et al., 2008; Lubatkin et al., 2006; O'Reilly - Tushman, 2004, 2008; Smith - Tushman, 2005; Tiwana, 2008).

\section{Current state of ambidexterity research}

Organizational ambidexterity is currently taking shape as a research paradigm in organizational theory (Raisch - Birkinshaw, 2008). Ambidexterity research is still in its infancy and has previously concentrated on demonstrating that focused firms show lower performance than ambidextrous ones (Brion - Mothe - Sabatier, 2010).

At first sight, organizational ambidexterity's antecedents, which include structural, contextual, and leadership-based factors, have been implicitly conceptualized as alternative solutions. Raisch and Birkinshaw's (2008) in-depth analysis of the literature, however, revealed complementarities between the different constructs. A common culture and vision, and supportive and flexible leaders, managers, top management teams and leadership processes are essential prerequisites of structural ambidexterity (Smith - Tushman, 2005; Tushman - O'Reilly, 1996). These are very similar to Gibson and Birkinshaw's (2004) elements of "organizational context". As Birkinshaw and Gupta (2013) stated, there is no single unit of an organization that does only one thing, consequently contextual ambidexterity should rather be a complement than a concurring construct of structural ambidexterity (Birkinshaw - Gibson, 2004).

To conclude, organizational context may include the structural context. There is an important role played by top management teams in fostering contextual ambidexterity: "organizational ambidexterity is not simply a matter of structure" (O'Reilly - Tushman, 2007, p. 14.). Recent in-depth studies have revealed more complementarities between the different constructs of ambidexterity: companies use different combinations of these alternative solutions and change cyclical, structural and contextual ambidexterity over time, depending on their current growth stage and on external factors (e.g. Chen - Katila, 2008; Kauppilla, 2010; Laplume - Dass, 2012; O'Reilly - Tushman, 2013). It's proved, that longterm growth is impossible without the simultaneous or cyclical pursuit of exploration and exploitation activities during a company's life cycle. But environmental circumstances, path dependencies and internal capabilities could shape how an organization can become balanced and ambidextrous in different growth phases (e.g. He - Wong, 2004; O'Reilly - Tushman, 2011). For example, Kauppilla (2010, p. 284.) stated, that "in reality, firms are likely to create ambidexterity through a combination of structural and contextual antecedents and at both organizational and interorganizational levels, rather than through any single organizational or interorganizational antecedent alone."

I therefore don't interpret the definition of ambidexterity as a choice between different alternatives. In my opinion, ambidexterity is the continuous and ongoing pursuit of balance between the efficient exploitation of current opportunities and the necessary exploration of new ones, using contextual, structural, or cyclical solutions or a combination of these. I believe that these constructs as complementary. I do not exclude the possibility that organizations may apply different patterns, but I assume that these differences are rooted largely in external factors. The interesting question is not whether one particular aspect is used or not, but how ambidexterity is achieved.

To conclude the current state of the field, the effect of ambidexterity on firm performance is well-researched (e.g. Gibson - Birkinshaw 2004; He - Wong 2004; Lubatkin et al. 2006). The research on the structural antecedents of organizational ambidexterity (Duncan, 1976; Tushman - O'Reilly, 1996) has been extended in the past fifteen years with the investigation of the roles played by contextual elements (Adler et al., 1999; Corso - Pellegrini, 2007; Gibson - Birkinshaw, 2004), informal networks (Gulati - Puranam, 2009), top management teams (Beckman, 2006; Lubatkin et al., 2006; Smith - Tushman, 2005), and environmental (Auh Menguc, 2005; Jansen et al., 2008) and organizational factors (Atuahene-Gima, 2005; Lubatkin et al., 2006; Kyriakopoulos - Moorman, 2004). The fragmented literature started to integrate and standardize, but we are at the beginning of the process, therefore several important research issues remain unexplored and ambiguous (Raisch - Birkinshaw, 2008).

\section{Research gap in organizational ambidexterity literature}

Based on the current state of the field, in this chapter I would like to highlight some important research gaps. Birkinshaw and colleagues (2014) examined the dominant focus of management research and methodology and called for more in-depth field studies to understand the complex phenomena of ambidexterity:

"First, we need more field observation. With some notable exceptions, as management and organization researchers we expend a tiny proportion of our energies actually observing the phenomena we want to understand. ... The benefits of close contact are many; not least insight, inspiration, curiosity, and ecological validity. The focus on management phenomena, first of all, suggests that we have to get our hands dirty and closely observe and study, or even live with, people in organizations-rather than relying on arm's length, or 
at worst ivory tower, approaches that are based on lab data or proxies.” (p. 47.)

Concentrating on organizational ambidexterity, O'Reilly and Tushman (2013) supported this critique, calling for more qualitative in-depth studies. This is because the core of ambidexterity is a complex and complicated management challenge with closely-related leadership, structural and contextual solutions, which are hardly separable. Consequently, scholars highlight the need for multi-level analyses, because ambidexterity is a nested construct spanning multiple organizational levels: leadership creates organizational context, structural solutions, planning and reward systems and decision-making processes, which in turn affect individual behavior patterns, culture, values and collective identity (Birkinshaw - Gupta, 2013; Gupta - Smith - Shalley, 2006; Raisch et al., 2009; Raisch - Birkinshaw, 2008). There is, therefore, a need to develop a deep understanding of complex managerial challenges through qualitative, in-depth field studies examining multiple levels of organizations.

Another issue in the field is that the majority of ambidexterity studies have examined large corporations and mature organizations, which have successfully applied ambidextrous management solutions. Little is known about how ambidexterity forms in a young firm and how structures, contexts and leadership patterns develop over time (O'Reilly - Tushman, 2013; Raisch - Birkinshaw, 2008). As Simsek et al. (2009, p. 888.) stated, "it is simply not known how business units or small organizations simultaneously attain exploitation and exploration."

Güttel and Konlechner (2009) suggested that researchers could explore how different ambidextrous designs are connected to different developmental stages of organizations. The literature calls researchers' attention to the missing or unspecified key elements of context, because without knowledge about drivers, systems and processes, researchers cannot understand contextual ambidexterity in sufficient depth (O'Reilly - Tushman, 2013; Simsek et al., 2009). Lavie, Stettner and Tushman (2010) asked why some organizations are able to be ambidextrous and others are not. To answer this question, they recommended the systematic examination of the organizational and managerial antecedents and different types of resources required for exploration-exploitation tendencies, and the trade-offs, costs and challenges of balancing efforts.

In summary, little is known about:

- how ambidexterity develops in the early growth stages of a firm,

- the drivers of ambidextrous organizational context, and
- how top and middle managers handle the formation process of ambidexterity.

\section{Future research plans}

Little is known about how small organizations or business units develop ambidextrous contexts, the drivers of these contexts and how leaders manage these processes and develop the human capital of the firm. There is a particular shortage of field observations and qualitative case studies examining how leaders manage the interfaces between exploration and exploitation, how organizations develop their contexts over time and how they overcome path dependencies (Birkinshaw et al., 2014; Lavie - Stettner - Tushman, 2010; O’Reilly - Tushman, 2013; Raisch - Birkinshaw, 2008; Simsek et al., 2009).

My research aim is therefore to understand which systems and processes are essential to support the evolution of ambidextrous organizational context, and the lack of which systems and processes holds this back. I also want to examine the roles played by top and middle management in this formation process. To answer my research questions, I apply case study-based, qualitative methodology with a longitudinal, historic approach.

As Birkinshaw and Gibson (2004) pointed out, generalist management skills and control and reward systems become important in an integrated organizational context. I would therefore like to examine fast-growing middle-sized companies, at a point just before and after Greiner's (1972) control crisis, because this is the critical point in organizational evolution when generalist middle management becomes the catalyst for market expansion in a decentralized organizational structure after an efficiency-focused phase driven by functionalist managers. Based on the literature on punctuated equilibrium and growth, I interpret growth crises as short, revolutionary periods in an organization's life cycle, when organizational transformations are accomplished via rapid and discontinuous change over most or all domains of organizational activity, and chief executive officer succession is an important factor of transformation (Romanelli - Tushman, 1994).

To conclude, based on Birkinshaw and Gibson (2004), I assume that this is the first phase during which organizations in dynamic environmental conditions should become able to pursue exploration and exploitation simultaneously. The reason for choosing contextual, rather than structural, ambidexterity as a conceptual framework is based on the assumption that the size of the organization and the involvement of a founder-manager in exploitative and explorative activities do not make it necessary or feasible to develop separated structures. Organizations may show different patterns along differentiation versus integration and simultaneous ver- 
sus cyclical ambidexterity tensions, but I assume that these differences are rooted in environmental factors, and that organizational context will integrate structural and leadership aspects in middle-sized companies.

\section{Conclusion}

This paper's aim is to comprehensively review the literature of organizational ambidexterity, as the currently most popular and active field in strategic management literature. It's well known, that successful organizations under dynamic environmental circumstances are ambidextrous, but finding the balance between the contradictory exploration and exploitation is an extremely difficult managerial challenge. In this paper I introduced (1) ambidexterity in general, (2) the traps that makes ambidexterity necessary for long-term success, (3) different aspects and subfields in the literature, (4) the theory's current state and (5) some important research gaps and my future research plans. As a result of the past 25 years' research, we know enough about different ambidexterity solutions (structural, contextual, leadership) and their performance implications, but several questions remained unanswered. The majority of prior researches examined already ambidextrous, large and mature organizations, but little is known about how ambidexterity forms in earlier growth stages. Future researches should focus on the process how this organizational ability develops and forms, and not on the verification of structural and contextual or any other approach. The current definition of organizational context (Ghoshal - Bartlett, 1994) is rough, therefore the managerial and structural drivers of ambidexterity is another important field of future researches. In my opinion, these gaps need to be investigated with qualitative, in-depth, multi-level and longitudinal methodology to better understand these uncovered questions.

\section{References}

Abernathy, W. J. - Clark, K. B. (1985): Innovation: Mapping the winds of creative destruction. Research Policy, (14): p. 3-22.

Adler, P. S. - Goldoftas, B. - Levine, D. I. (1999): Flexibility versus efficiency: A case study of model changeovers in the Toyota production system. Organization Science, 10: p. 43-68.

Ahuja, G. - Lampert, C. (2001): Entrepreneurship in the large corporation: A longitudinal study of how established firms create breakthrough inventions. Strategic Management Journal, (22): p. 521-543.

Ancona, D. G. - Goodman, P. S. - Lawrence, B. S. Tushman, M. L. (2001): Time: A new research lens. Academy of Management Review, (26): p. 645-663.
Argyris, C. - Schön, D. (1978): Organizational learning: A theory of action perspective. Reading, MA: Addison- Wesley

Atuahene-Gima, K. (2005): Resolving the capability-rigidity paradox in new product innovation. Journal of Marketing, (69): p. 61-83.

Auh, S. - Menguc, B. (2005): Balancing exploration and exploitation: The moderating role of competitive intensity. Journal of Business Research, (58): p. 16521661.

Balaton, K. - Hortoványi, L. - Incze, E. - Laczkó, M. - Szabó, Zs. R. - Tari, E. (2014): Stratégiai menedzsment. Budapest: Akadémiai Kiadó

Balaton, K. - Tari, E. (ed.) (2014): Stratégiai és üzleti tervezés. Budapest: Akadémiai Kiadó

Beckman, C. M. (2006): The influence of founding team company affiliations on firm behavior. Academy of Management Journal, 49(4): p. 741-758.

Benner, M. J. - Tushman, M. L. (2003): Exploitation, exploration, and process management: The productivity dilemma revisited. Academy of Management Review, 28(2): p. 238-256.

Birkinshaw, J. - Hamel, G. - Mol, M. (2008): Management Innovation. Academy Of Management Review, 33(4): p. 825-845.

Birkinshaw, J. - Healey, M. P. - Suddaby, R. - Weber, K. (2014): Debating the Future of Management Research. Journal of Management Studies, 51(1): p. 38-55.

Birkinshaw, J. - Gibson, C. B. (2004): Building Ambidexterity into an Organization. MIT Sloan Management Review, 45(4): p. 47-55.

Birkinshaw, J. - Gupta, K. (2013): Clarifying the Distinctive Contribution of Ambidexterity to the Field of Organization Studies. Academy of Management Perspectives, 27(4): p. 287-298.

Brion, S. - Mothe, C. - Sabatier, M. (2010): The Impact of Organisational Context and Competences on Innovation Ambidexterity. International Journal of Innovation Management, 14(2): p. 151-178.

Brown, S. L. - Eisenhardt, K. (1997): The art of continuous change: Linking complexity theory and timepaced evolution in relentlessly shifting organizations. Administrative Science Quarterly, (42): p. 1-34.

Brown, S. L. - Eisenhardt, K. (1998): Competing on the edge: Strategy as structured chaos. Cambridge, MA: Harvard Business School Press

Burgelman, R. A. (1991): Intraorganisational Ecology of Strategy Making and Organizational Adaption: Theory and Field Research. Organizational Science, 2(3): p. 239-262.

Burgelman, R. A. (2002): Strategy as vector and the inertia of coevolutionary lock-in. Administrative Science Quarterly, (47): p. 325-357.

Burns, T. - Stalker, G. M. (1961): The management of in- 
novation. London: Tavistock

Carland, J. W. - Hoy, F. - Boulton, R. W. - Carland, J. A. C. (1984): Differentiating entrepreneurship from small business owners: a conceptualization. Academy of Management Review, (9)2: p. 358.

Chesbrough, H. - Rosenbloom, R. S. (2002): The role of the business model in capturing value from innovation: Evidence from Xerox Corporation's technology spin-off companies. Industrial and Corporate Change, (11): p. 529-555.

Chen, E. L. - Katila, R. (2008): Rival interpretations of balancing exploration and exploitation: Simultaneous or sequential? in: S. Scott (ed.): Handbook of technology and innovation management. New York: Wiley: p. 197- 214.

Cheng, Y. T. - Van de Ven, A. H. (1996): Learning the Innovation Journey: Order out of Chaos? Organization Science, (7): p. 593-614.

Christensen, C. M. (1998): The innovator's dilemma. Cambridge, MA.: Harvard Business School Press

Christensen, C. M. - Overdorf, M. (2000): Meeting the challenges of disruptive change. Harvard Business Review, 78(2): p. 66.

Cole, A. H. (1968): The entrepreneur: Introductory remarks. American Economic Review, (5): p. 62.

Corso, M. - Pellegrini, L. (2007): Continuous and discontinuous innovation: overcoming the innovator dilemma. Creativity and Innovation Management, (16): p. 333-347.

Crozier, M. (1964): The bureaucratic phenomenon. Chicago: University of Chicago Press

D'Aveni, W. (1994): Hypercompetition: Managing the Dynamics of Strategic Maneuvering. New York: Free Press

Dewar, R. D. - Dutton, J. E. (1986): The adoption of radical and incremental innovations: An empirical analysis. Management Science, (32): p. 1422-1433.

Dougherty, D. (1992): Interpretive barriers to successful product innovation in large firms. Organization Science, (3): p. 179-202.

Drucker, P. F. (1985): Innovation and entrepreneurship: Practice and principles. New York: Harper - Row

Drucker, P. F. (1969): Management's new role. Harvard Business Review, (6): p. 52.

Drucker, P. F. (1998): The discipline of innovation. Harvard Business Review, (6): p. 179.

Duncan, R. B. (1976): The ambidextrous organization: Designing dual structures for innovation. in: R. H. Kilmann - L.R. Pondy - D. Slevin (eds.): The management of organization design: Strategies and implementation. New York: North Holland: p. 167-188.

Eisenhardt, K. M. (2000): Paradox, spirals, ambivalence: The new language of change and pluralism. Academy of Management Review, (25): p. 703-705.
Fauchart, E. - Keilbach, M. (2009): Testing a model of exploration and exploitation as innovation strategies. Small Business Economics, 33(3): p. 257-272.

Ford, J. D. - Ford, L. W. (1994): Logics of identity, contradiction, and attraction in change. Academy of Management Review, (19): p. 756-795.

Galbraith, J. K. (2002): Organizing to deliver solutions. Organizational Dynamics, 31(2): p. 194-206.

Gavetti, G. - Levinthal, D. (2000): Looking forward and looking backward: Cognitive and experiential search. Administrative Science Quarterly, (45): p. 113-137.

Ghemawat, P. - Ricart i Costa, J. (1993): The organizational tension between static and dynamic efficiency. Strategic Management Journal, (14): p. 59-73.

Ghoshal, S. - Bartlett, C. (1994): Linking organizational context and managerial action: The dimensions of quality in management. Strategic Management Journal, 15: p. 91-112.

Gibson, C. B. - Birkinshaw, J. (2004): The Antecedents, Consequences, and Mediating Role of Organizational Ambidexterity. Academy of Management Journal, 47(2): p. 209-226.

Gilbert, $C$. (2005): Unbundling the structure of inertia: Resource versus routine rigidity. Academy of Management Journal, (48): p. 741-763.

Greiner, L. E. (1972): Evolution and revolution as organizations grow. Harvard Business Review, 50(4): p. 3746.

Gulati, R. - Puranam, P. (2009): Renewal Through Reorganization: The Value of Inconsistencies Between Formal and Informal Organization. Organization Science, 20(2): p. 422-440.

Gupta, A. K. - Smith, K. G. - Shalley, C. E. (2006): The interplay between exploration and exploitation. Academy of Management Journal, 49(4): p. 693-706.

Güttel, W. H. - Konlechner, S. W. (2009): Continuously Hanging by a Thread: Managing Contextually Ambidextrous Organizations. Schmalenbach Business Review, 71(2): p. 150-172.

Hamel, G. - Prahalad, C. K. (1993): Strategy as stretch and leverage. Harvard Business Review, (71): p. 75-84.

Han, M. (2007): Achieving Superior Internationalization through Strategic Ambidexterity. Journal of Enterprising Culture, 15(1): p. 43-77.

Han, M. - Celly, N. (2008): Strategic Ambidexterity and Performance in International New Ventures. Canadian Journal of Administrative Sciences, 25: p. 335-349.

Hannan, M. T. - Freeman, J. H. (1984): Structural inertia and organizational change. American Sociological Review, (49): p. 149-164.

Hannan, M. T. - Freeman, J. H. (1977): The population ecology of organizations. American Journal of Sociology, (82): p. 929-964.

He, Z-L. - Wong, P-K. (2004): Exploration vs. Exploita- 
tion: An Empirical Test of the Ambidexterity Hypothesis, 15(4): p. 481-494.

Herriott, S. R. - Levinthal, D. A. - March, J. G. (1985): Learning from experience in organizations. American Economic Review, (75): p. 298-302.

Holmqvist, M. (2004): Experiential learning processes of exploitation and exploration within and between organizations: An empirical study of product development. Organization Science, (15): p. 70-81.

Huy, O. N. (2002): Emotional balancing of organizational continuity and radical change: The contribution of middle managers. Administrative Science Quarterly, 47(1): p. 31-69.

Jansen, J. J. P. - George, G. - Van den Bosch, F. A. Volberda, H. W. (2008): Senior team attributes and organizational ambidexterity: The moderating role of transformational leadership. Journal of Management Studies, 45(5): p. 982-1007.

Jansen, J. J. P. - Van den Bosch, F. A. J. - Volberda, $H$. W. (2006): Exploratory Innovation, Exploitative Innovation, and Performance: Effects of Organizational Antecedents and Environmental Moderators. Management Science, 52(11): p. 1661-1674.

Kauppila, $O$. (2010): Creating ambidexterity by integrating and balancing structurally separate interorganizational partnerships. Strategic Organization, 8(4): p. 283-312.

Kouropalatis, Y. - Hughes, P. - Morgan, R. E. (2012): Pursuing 'Flexible Commitment' as strategic ambidexterity: an empirical justification in high technology firms. European Journal of Marketing, 46 (10): p. 1389-1417. doi: 10.1108/03090561211248099

Kyriakopoulos, K. - Moorman, C. (2004): Tradeoffs in marketing exploitation and exploration strategies: the overlooked role of market orientation. International Journal of Research in Marketing, (21): p. 219-240.

Laplume, A. O. - Dass, P. (2012): Exploration and exploitation for various stages of firm growth through diversification. Paper presented at the annual meetings of the Academy of Management, Boston, August of 2012.

Lavie, D. - Rosenkopf, L. (2006): Balancing exploration and exploitation in alliance formation. Academy of Management Journal, 49(4): p. 797-818.

Lavie, D. - Stettner, U. - Tushman, M. L. (2010): Exploration and Exploitation Within and Across Organizations. The Academy of Management Annals, 4(1): p. 109-155.

Lawrence, P. R. - Lorsch, J. W. (1967): Organization and environment: Managing differentiation and integration. Cambridge, MA: Harvard University Press

Leana, C., - Barry, B. (2000): Stability and change as simultaneous experiences in organizational life. Academy of Management Review, (25): p. 753-759.
Leonard-Barton, D. (1992): Core capabilities and core rigidities: A paradox in managing new product development. Strategic Management Journal, (13): p. 111-125.

Leonard-Barton, D. (1995): Wellsprings of knowledge. Cambridge, MA: Harvard Business School Press

Lewin, A. Y. - Long, C. P. - Carroll, T. N. (1999): The coevolution of new organizational forms. Organization Science, (10): p. 535-550.

Levinthal, D. (1997): Adaptation on rugged landscapes. Management Science, (43): p. 934-950.

Levinthal, D. - March, J. (1993): Myopia of learning. Strategic Management Journal, (14): p. 95-112.

Levitt, B. - March, J. G. (1988): Organizational learning. in: W. R. Scott (ed.): Annual review of sociology, (14), Palo Alto, CA: Annual Reviews: ): p. 319- 340.

Lewis, M. W. (2000): Exploring paradox: Toward a more comprehensive guide. Academy of Management Review, 25: p. 760-777.

Lubatkin, M. H. - Simsek, Z. - Ling, Y. - Veiga, J. F. (2006): Ambidexterity and performance in small- to medium-sized firms: The pivotal role of top management team behavioral integration. Journal of Management, 32(5): p. 646-672.

Mahmoud-Jouini, S. B. - Charue-Duboc, F. - Fourcade, $F$. (2007): Multilevel Integration of Exploration Units: Beyond the Ambidextrous Organization. Academy of Management Best Paper Proceedings, 08/2007.

March, J. G. (1991): Exploration and exploitation in organizational learning. Organization Science, (2): p. 71-87.

McGill, M. E. - Slocum, J. W. - Lei, D. (1992): Management practices in learning organizations. Organization Dynamics, 21(1): p. 5-17.

Meyer, C. B. - Stensaker, I. G. (2006): Developing capacity for change. Journal of Change Management, 6(2): p. 217-231.

Mészáros, T. (2011): Traditional and new elements in strategic thinking. International Journal of Management Cases, (13): p. 845-865. doi: http://dx.doi.org/10.5848/ APBJ.2012.00015

Miller, D. - Friesen, P. H. (1984): Organizations: A quantum view. Englewood Cliffs, NJ: Prentice Hall

Mitchell, W. - Singh, K. (1993): Death to the lethargic: Effects of expansion into new technical subfields on performance in a firm's base business. Organization Science, (4): p. 152-180.

Mom, T. J. M. - Van Den Bosch, F. A. J. - Volberda, H. $W$. (2007): Investigating Managers' Exploration and Exploitation Activities: The Influence of Top-Down, Bottom-Up, and Horizontal Knowledge Inflows. Journal of Management Studies, 44(6), September 2007: p. 910-931.

O'Reilly, C. A. - Tushman, M. L. (2008): Ambidexterity as a dynamic capability: Resolving the innovator's di- 
lemma. Research in Organizational Behavior, (28): p. 185-206.

O'Reilly, G. A. - Harreld, J. B. - Tushman, M. L. (2009): Organizational ambidexterity: IBM and emerging business opportunities. California Management Review, (51): p. 1-25.

O'Reilly, C. -Tushman, M.L. (2011): Organizational Ambidexterity in Action: How Managers Explore and Exploit. California Management Review, 53(4): p. 5-22.

O'Reilly, C. A. - Tushman, M. L. (2013): Organizational Ambidexterity: Past, Present, and Future. The Academy of Management Perspectives, 27(4): p. 324-338.

O'Reilly, C. A. - Tushman, M. L. (2004): The ambidextrous organization. Harvard Business Review, (82): p. 74-81.

Penrose, E. T. (1959): The Theory of the Growth of the Firm. Oxford: Basil Blackwell

Porter, M. E. (1993): Versenystratégia, ipari ágak és versenytársak elemzési módszerei. Budapest: Akadémiai Kiadó

Prahalad, C. K. - Bettis, R . (1984): The dominant logic: A new linkage between diversity and performance. Strategic Management Journal, 7(6): p. 485-501.

Raisch, S. - Birkinshaw, J. (2008): Organizational Ambidexterity: Antecedents, Outcomes, and Moderators. Journal of Management, 34(3): p. 375-409.

Raisch, S. - Birkinshaw, J. - Probst, G. - Tushman, M.L. (2009): Organizational Ambidexterity: Balancing Exploitation and Exploration for Sustained Performance. Organization Science, 20(4): p. 685-695.

Rothaermel, F. T. - Deeds, D. L. (2004): Exploration and exploitation alliances in biotechnology. Strategic Management Journal, (25): p. 201-221.

Russo, A. - Vurro, C. (2010): Cross-boundary ambidexterity: Balancing exploration and exploitation in the fuel cell industry. European Management Review, (7): p. 30-45.

Senge, P. M. (1990): The fifth discipline: Mastering the five practices of the learning organization. New York: Doubleday

Schumpeter, J. A. (1934): The theory of economic development. Cambridge, MA: Harvard University Press

Sheremata, W. (2000): Centrifugal and centripetal forces in radical new product development under time pressure. Academy of Management Review, (25): p. 389408.

Siggelkow, N. - Levinthal, D. A. (2003): Temporarily divide to conquer: Centralized, decentralized, and reintegrated organizational approaches to exploration and adaptation. Organization Science, (14): p. 650-669.

Simsek, Z. - Heavey, C. - Veiga, J.F. - Souder, D. (2009): A Typology for Aligning Organizational Ambidexterity's Conceptualizations, Antecedents, and Outcomes. Journal of Management Studies, 46, 5: p. 864-894.
Smith, W. - Binns, A. - Tushman, M. (2010): Complex business models: Managing strategic paradoxes simultaneously. Long Range Planning, (43): p. 448-461.

Smith, W. K. - Lewis, M. W. (2011): Toward a theory of paradox: A dynamic equilibrium model of organizing. Academy of Management Review, 36(2): p. 381-403.

Smith, W. - Tushman, M. L. (2005): Managing strategic contradictions: A top management model for managing innovation streams. Organization Science, 16(5): p. 522-536.

Stevenson, H. H. - Gumpert, D. E. (1985): The heart of entrepreneurship. Harvard Business Review, (3): p. 8792.

Szabó, Zs. R. (2008): Adaptációs stratégiák a kialakuló bioetanol-iparágban. Vezetéstudomány (Budapest Management Review), 39(11): p. 54-63.

Thompson, J. D. (1967): Organizations in action. New York: McGraw Hill

Tiwana, A. (2008): Do bridging ties complement strong ties? An empirical examination of alliance ambidexterity. Strategic Management Journal, (9): p. 251-272.

Tushman, M.L. - Anderson, P. (1986): Technological discontinuities and organizational environments. Administrative Science Quarterly, (31): p. 439-465.

Tushman, M. L. - O'Reilly, C. A. (1996): Ambidextrous organizations: Managing evolutionary and revolutionary change. California Management Review, 38(4): p. 8-30.

Tushman, M. L. - Romanelli, E. (1985): Organizational evolution: A metamorphosis model of convergence and reorientation. in: L. L. Cummings - B. M. Star (eds.): Research in Organizational Behavior, (7): p. 171-222.

Tushman, M. L. - Smith, W. K. (2002): Organizational technology. in: J. Baum (ed.): Companion to organization. Malden, MA: Blackwell: p. 386-414.

Van den Bosch, F. A. J. - Volberda, H. W. - de Boer, M. (1999): Coevolution of firm absorptive capacity and knowledge environment: Organizational forms and combinative capabilities. Organization Science, (10): p. 551-568.

Volberda, H. (1996): Toward the flexible form: How to remain vital in hypercompetitive environments? Organization. Science, 7(4): p. 359-374.

Volberda, H. - Baden-Fuller, C. - van den Bosch, F. A. $J$. (2001): Mastering strategic renewal: Mobilizing renewal journeys in multi-unit firms. Long Range Planning, (34): p. 159-178.

Volberda, H. - Lewin, A. (2003): Co-evolutionary dynamics within and between firms: From evolution to coevolution. Journal of Management Studies, (40): p. 2111-2136.

Winter, S. G. - Szulanski, G. (2001): Replication as strategy. Organization Science, (12): p. 730-743. 